\title{
An unlabelled probe-based real time PCR and modified semi-nested PCR as molecular tools for analysis of chloroquine resistant Plasmodium vivax isolates from Afghanistan
}

\author{
Sayed Hussain Mosawi ${ }^{1,2}$, Abdolhossein Dalimi ${ }^{1 *} \mathbb{B}$, Najibullah Safi ${ }^{3}$, Reza Fotouhi-Ardakani ${ }^{4}$,
} Fatemeh Ghaffarifar ${ }^{1}$ and Javid Sadraei ${ }^{1}$

\begin{abstract}
Background: Plasmodium vivax resistance to chloroquine (CQ) has been reported from many endemic regions in the world. Plasmodium vivax is responsible for $95 \%$ of malaria cases in Afghanistan and CQ is the first-line treatment given for vivax malaria. The pvmdr-1 and pvcrt-o (K10 insertion) genes are possible markers for CQ-resistance in P. vivax isolates. There have been no studies done on the presence or absence of molecular markers for CQ-resistance $P$. vivax in Afghanistan. The present work aimed to evaluate the frequency of mutations in the pvmdr-1 and K10 insertion in the pvcrt-o genes of P. vivax.

Methods: Plasmodium vivax isolates were collected from Laghman, Baghlan and Khost provinces. For investigation of polymorphisms of desired regions in pvmdr-1 and pvcrt-o genes, sequencing was applied on the PCR products. A new asymmetric qPCR and melting analysis assay based on unlabelled probe developed for scanning of K10 insertion in pvcrt-o gene.

Results: The analysis of sequencing data of the pvmdr-1 gene showed wild type Y976 and K997 and mutant M958 and L1076 in 33 isolates from three provinces. Of the 36 samples evaluated for $\mathrm{K} 10$ insertion in pvcrt-0, 2/18(11\%), 0/10(0\%) and 0/8(0\%) isolates from Laghman, Baghlan and Khost province, respectively, possessed K10 insertion, confirmed by either sequencing and unlabelled probes.

Conclusion: Two samples with K10 insertion and 33 samples with pvmdr1 polymorphism, indicating on the possibility of CQ resistance in P. vivax populations in Afghanistan. Furthermore, unlabelled probes are simple and inexpensive alternative tools for screening of $P$. vivax mutations.
\end{abstract}

Keywords: Plasmodium vivax, pvmdr-1, pvcrt-o, Chloroquine resistance, Afghanistan

\section{Background}

About 216 million cases of malaria were reported from 91 countries during 2016. Afghanistan has 13\% $(138,217)$ of malaria cases in the eastern Mediterranean region

*Correspondence: dalimi_a@modares.ac.ir

${ }^{1}$ Department of Medical Parasitology, Faculty of Medical Sciences, Tarbiat Modares University, Tehran, Iran

Full list of author information is available at the end of the article and $95.6 \%(132,237)$ of these cases were vivax malaria [1]. Because of its relatively low mortality, Plasmodium vivax is second in priority among the causative agents of malaria in the world, and has the widest geographical distribution when compared with the other species of human malaria parasites [2]. Most tropical areas, including the Middle East, Asia, and the Western Pacific, account for about $80-90 \%$ of vivax malaria outside of Africa [3]. Although severe malaria (characterized

(c) The Author(s) 2020. This article is licensed under a Creative Commons Attribution 4.0 International License, which permits use, sharing, adaptation, distribution and reproduction in any medium or format, as long as you give appropriate credit to the original author(s) and the source, provide a link to the Creative Commons licence, and indicate if changes were made. The images or other third party material in this article are included in the article's Creative Commons licence, unless indicated otherwise in a credit line to the material. If material is not included in the article's Creative Commons licence and your intended use is not permitted by statutory regulation or exceeds the permitted use, you will need to obtain permission directly from the copyright holder. To view a copy of this licence, visit http://creativeco mmons.org/licenses/by/4.0/. The Creative Commons Public Domain Dedication waiver (http://creativecommons.org/publicdomain/ zero/1.0/) applies to the data made available in this article, unless otherwise stated in a credit line to the data. 
by cerebral malaria, renal failure, circulatory collapse, severe anaemia, haemoglobinuria, abnormal bleeding, ARDS, and jaundice) is mainly caused by Plasmodium falciparum, there is now accumulating evidence showing that $P$. vivax can also cause severe malaria in humans [4]. The first reports of chloroquine (CQ) resistant malaria was published in1959 for $P$. falciparum and in 1989 for $P$. vivax, when the malaria CQ-resistance studies were started in Afghanistan [5-7]. The P. falciparum CQ resistance was very worrying issue at the time, since it took many lives in several countries, mainly in Asia. Therefore, to avoid having the same situation with $P$. vivax, extensive, rapid and wide research must be performed [8]. Some of main causes for failure to control and eradicate vivax malaria are the emergence of antimalarial drug resistant strains and their ability to become dormant stages that could later on relapses weeks or months after the initial infection [9].

The first cases of chloroquine-resistant $P$. vivax were reported in Papua New Guinea and after that many more cases were observed in other parts of the world [5]. While reports of CQ-resistant $P$. vivax infections are increasing, this drug is still the primary therapy for vivax malaria in many endemic countries [6]. Chloroquine has been widely used in the treatment of uncomplicated malaria in Afghanistan since the 1940s, and remains the most widely used anti-malarial drug [10].

Although there are few studies have been done to assess CQ resistance, no work has been done to evaluate CQ efficacy on vivax malaria in Afghanistan [11-13]. Many studies have been performed to analyse the single point mutations in the pvmdr1 gene on chromosome 5 and pvcrt-o gene on chromosome 1 , and to evaluate their relation to the resistance of $P$. vivax to chloroquine [14]. Some studies have failed to demonstrate an association between pvmdr-1 and pvcrt-o mutations with the CQ resistance in $P$. vivax, and further investigations are needed to confirm these associations $[15,16]$. Research studies in some parts of the Brazilian Amazon, analysed polymorphisms within the coding and noncoding sequences of $p v m d r-1$ and pvcrt-o genes and the copy number variation in the pvmdr-1 gene [14, 17]. Melo et al. showed that patients with CQR showed an increase up to 6.1-fold and 2.4-fold in pvcrt-o and pvmdr-1 expression levels, compared to the susceptible population in this region that highlighted the association of pvcrt-o and pvmdr-1 with CQR P. vivax malaria [18]. Other studies also supported the effect of pvcrt-o gene on CQ transportation or accumulation by $P$. vivax [19]. Suwanarusk et al. [20] also showed an association between the CQ susceptibility of $P$. vivax, the amplification of the $p v m d r-1$ gene and the relevant SNPs. Brega et al. found polymorphisms at two different codons of the pvmdr-1 gene (positions Y976F and F1076L) [21]. Another study in Madagascar, showed the possible relationships between the pvcrt-o, pvmdr-1 genes and the clinical responses of the patients to CQ treatment [22]. Some studies reported that the Y976F mutation in the $p v m d r-1$ gene were associated with a reduction in CQ susceptibility of $P$. vivax isolates in vitro $[23,24]$. Some reports suggest the Y976F and the F1076L polymorphisms are common in Latin America [25]. Ganguly et al. investigated the prevalence of pvcrt$o$ and pvmdr-1 gene polymorphisms and the in vivo efficacy of CQ in P. vivax isolates from India [26]. So far, such studies have not been done in Afghanistan. There are several methods to analyse point mutations such as PCR-sequencing, ARMS-PCR, PCR-RFLP. One of the new techniques for the detection of polymorphisms of genes is asymmetric qPCR and using unlabelled probes [27]. In this study, for the first time the insertion of K10 in the pvcrt-o gene was investigated using a modified semi-nested PCR-sequencing approach and an asymmetric qPCR method. Successful and accurate detection of drug-resistant $P$. vivax parasites may be helpful in malaria control programmes, as well as treatment and elimination strategies [28]. This work aimed to evaluate the mutations of CQ-resistant associated genes in P. vivax isolates from three endemic provinces of Afghanistan.

\section{Methods}

\section{Locations, Plasmodium vivax samples collection and DNA purification}

In general, 50, 15, and $15 P$. vivax microscopically confirmed cases were collected from the patients that were referred to malaria diagnostics centres in Laghman (34 North, $70^{\circ}$ East), Baghlan (36 North and $68^{\circ}$ East) and Khost (33 $3^{\circ}$ North and $70^{\circ}$ East) provinces (Fig. 1), respectively, during 2017. For this, finger stick blood samples were spotted on DNA Banking Cards (DBCs) (Kowsar Biotechnology Center, Tehran, Iran) and microscope slides.

\section{DNA extraction and Plasmodium vivax confirmation}

Disks (2 $\mathrm{mm}$ in diameter) were punched out from each DBCs and washed 3 times with DBCs purification buffer and twice with distilled water. The disks were air dried and used directly as template of PCR processing [29]. A semi-nested multiplex PCR were performed on each sample for final confirmation of P. vivax [30].

\section{Evaluation of $p v m d r 1$ mutations by nested-PCR}

Briefly, in first round $p v m d r-1$ (OF) and $p v m d r-1$ (OR) primers (Table 1), were applied for amplification of about $967 \mathrm{bp}$ fragment of $p v m d r-1$ gene of $P$. vivax. 


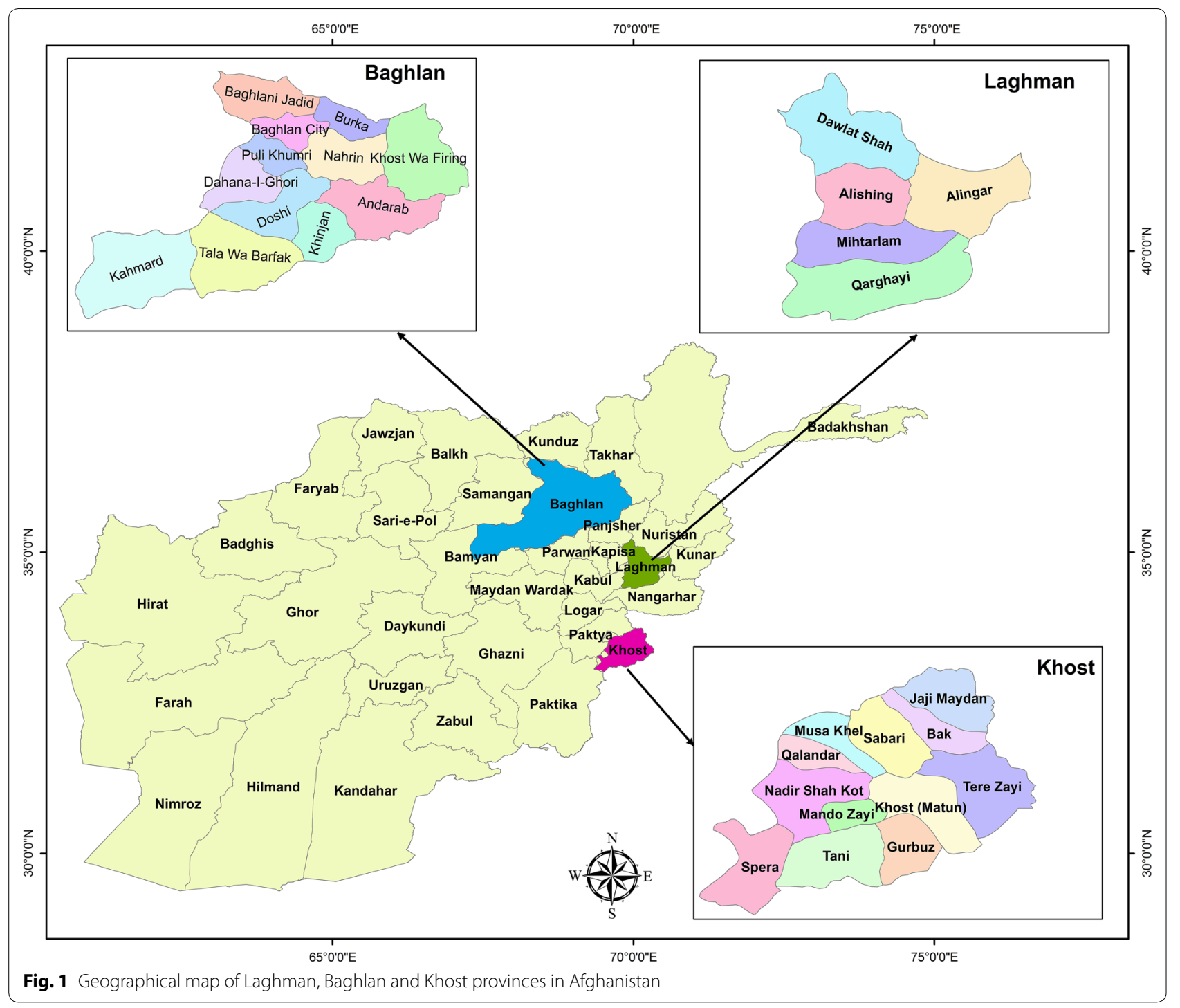

Table 1 Primers used for amplifications of pvcrt-o and pvmdr-1 marker genes: OF (Outer forward), OR (outer reverse), NF (nested forward), NR (nested reverse)

\begin{tabular}{llll}
\hline Primers & Sequences $\mathbf{5}^{\prime} \rightarrow \mathbf{3}^{\prime}$ & Final size (bp) & $\begin{array}{l}\text { Annealing } \\
\text { temp. }\left({ }^{\circ} \mathbf{C}\right)\end{array}$ \\
\hline Pvmdr-1 (OF) & CGCCATTATAGCCCTGAGCA & 604 & 60 \\
Pvmdr-1 (OR) & TCTCACGTCGATGAGGGACT & \\
Pvmdr-1 (NF) & $\begin{array}{l}\text { GGATAGTCATGCCCCAGG } \\
\text { ATTG }\end{array}$ & 57 \\
Pvmdr-1 (NR) & CATCAACTTCCCGGCGTAGC \\
Pvcrt-o F & AAGAGCCGTCTAGCCATCC & 296 \\
Pvcrt-o R & AGTTTCCCTCTACACCCG & 52 \\
Pvcrt-o (Rseq) & GGGGACGTCCTCTTGTATTT & \\
\hline
\end{tabular}

Three punched discs were used for each PCR reaction of the first round. One microlitre of all products of the first round diluted into $500 \mu \mathrm{l}$ of sterile water. In the second round $1 \mu \mathrm{l}$ of $p v m d r-1$ (NF) and pvmdr-1 (NR) primers (Table 1 ) and $2 \mu \mathrm{l}$ of diluted product of the first round were added into $25 \mu \mathrm{l}$ of " $2 \mathrm{X}$ Taq Master Mix Red" (Amplicon inc., containing 150 mMTris-Cl pH 8.5, $40 \mathrm{mM}$ (nh4) 2So4, $3 \mathrm{mM} \mathrm{Mgcl} 2,0.2 \%$ tween 20, $0.4 \mathrm{mM}$ dntPs, $0.05 \mathrm{U} / \mu \mathrm{l}$ Taq DNA polymerase, inert red dye and stabilizer), to reach a final concentration of $50 \mu \mathrm{l}$. The first round was done in $94{ }^{\circ} \mathrm{C}, 5 \mathrm{~min} ; 30$ cycles of $94{ }^{\circ} \mathrm{C}, 15 \mathrm{Sec} ; 60{ }^{\circ} \mathrm{C}$, $30 \mathrm{Sec} ; 72{ }^{\circ} \mathrm{C}, 1 \mathrm{~min} ; 72{ }^{\circ} \mathrm{C}$, $7 \mathrm{~min}$, while the second round PCR was done under the 
following conditions: $94{ }^{\circ} \mathrm{C}, 5 \mathrm{~min} ; 30$ cycles of $94{ }^{\circ} \mathrm{C}$, 15 Sec; $57{ }^{\circ} \mathrm{C}, 30 \mathrm{Sec} ; 72{ }^{\circ} \mathrm{C}, 1 \mathrm{~min} ; 72{ }^{\circ} \mathrm{C}, 7 \mathrm{~min}$. The products of the second round (604 bp) were seen in $2 \%$ agarose gels (SYBR Safe stain; Invitrogen; Groningen, The Netherlands). The pvmdr-1 (NF) and PCR products were sent for sequencing by the ABI3730XL sequence analyzer (Macrogen, Korea) [8].

\section{Evaluation of pvcrt-o K10 insertion by semi-nested PCR}

Briefly in first round pvcrt-o (OF) and pvcrt-o (OR) primers (Table 1), were applied for amplification of about 1186 bp fragment of pvcrt-o gene of $P$. vivax. Three punched discs were used for each PCR reaction of the first round. One microlitre of all products of the first round diluted into $500 \mu \mathrm{l}$ of sterile water. In the second round the $1 \mu \mathrm{l}$ of pvcrt-o(OF) and pvcrt-o (Rseq) primers (Table 1) and $2 \mu \mathrm{l}$ of diluted product of first round were added into 25 microlitre of "2X Taq Master Mix Red" (Amplicon Inc.), to reach a final concentration of $50 \mu \mathrm{l}$. The first round was done in $95{ }^{\circ} \mathrm{C}, 5 \mathrm{~min} ; 30$ cycles of $94{ }^{\circ} \mathrm{C}, 15 \mathrm{~s} ; 52{ }^{\circ} \mathrm{C}, 30 \mathrm{~s} ; 72{ }^{\circ} \mathrm{C}, 90 \mathrm{~s} ; 72{ }^{\circ} \mathrm{C}, 7 \mathrm{~min}$, while the second round PCR was done under the following conditions: $94{ }^{\circ} \mathrm{C}, 5 \mathrm{~min} ; 30$ cycles of $94{ }^{\circ} \mathrm{C}, 15 \mathrm{~s} ; 55^{\circ} \mathrm{C}$, $30 \mathrm{~s} ; 72{ }^{\circ} \mathrm{C}, 30 \mathrm{~s} ; 72{ }^{\circ} \mathrm{C}, 7 \mathrm{~min}$. The products of the second round (296 bp) were seen in $2 \%$ agarose gels (SYBR Safe stain; Invitrogen; Groningen, The Netherlands). The Pvcrt-o(OF) and PCR products were sent for sequencing by the ABI3730XL sequence analyzer (Macrogen, Korea) $[8,31]$.
Development of asymmetric real time PCR and melt-curve analysis

\section{Primer and probe design}

The genomic sequence of $P$ vivax (accession number: EU33972) was imported into CLC Main Workbench 5 (CLC bio, Aarhus, Denmark) Software. The Pvcrto-OF primer was selected as forward primer [8] and a reverse primer was designed for pvcrt-o gene. Then a probe designed that contain the insertion of interest. The probe blocking improved by amino-modified C6 to prevent extension during PCR amplification. The primers, probe sequences, and their position in the pvcrt-o gene are presented in Table 2 and Fig. 2.

\section{Amplification conditions}

The qPCR-HRM assay was performed using an ABI 7500 Fast Real-time PCR system (Applied Biosystems, Inc.). The PCR was set up in a final volume of $20 \mu \mathrm{l}$ containing $0.1 \mu \mathrm{M}$ of Pvcrt0-OF (forward primer), $0.5 \mu \mathrm{M}$ Afg. HRM. $R$ (the reverse primer and the excess primer) and $0.5 \mu \mathrm{M}$ Afg.U.P probe, $2 \mu \mathrm{l}$ of diluted product of first round from semi nested PCR and $4 \mu$ of 5 X Hot Firepol ${ }^{\circledR}$ EvaGreen ${ }^{\circledR}$ HRM Mix (Solis BioDyne, Tartu, Estonia) in qPCR 8-strip tubes (Gunster Biotech, Taiwan).

The thermal program included an initial denaturation at $95{ }^{\circ} \mathrm{C}$ for $12 \mathrm{~min}$, followed by 40 cycles of amplification consisting of $95^{\circ} \mathrm{C}$ for $15 \mathrm{~s}$ (denaturation step), $60{ }^{\circ} \mathrm{C}$ for $20 \mathrm{~s}$ (primer annealing), and $72^{\circ} \mathrm{C}$ for $20 \mathrm{~s}$ (elongation step). The amplicons were then subject to a melt program

Table 2 High-resolution melting assay primer and probe sequences used for detection K10 insertion in pvcrt-o gene

\begin{tabular}{lllll}
\hline Name & Primer/probe & Sequence $\mathbf{5}^{\prime} \rightarrow \mathbf{3}^{\prime}$ & TM & Products size \\
\cline { 3 - 4 } & & & Wild & Mutant \\
\hline Pvcrto-OF & Forward primer & GCTACCCCTAACGCACAATG & 80 \\
Afg.HRM. R & Reverse primer & CCGGTAACGTTCATCGG & 83 \\
Afg.U.P & Unlabelled Probe & CTGAAAAAGAGAAGAAGAAGGG- block & \\
\hline
\end{tabular}

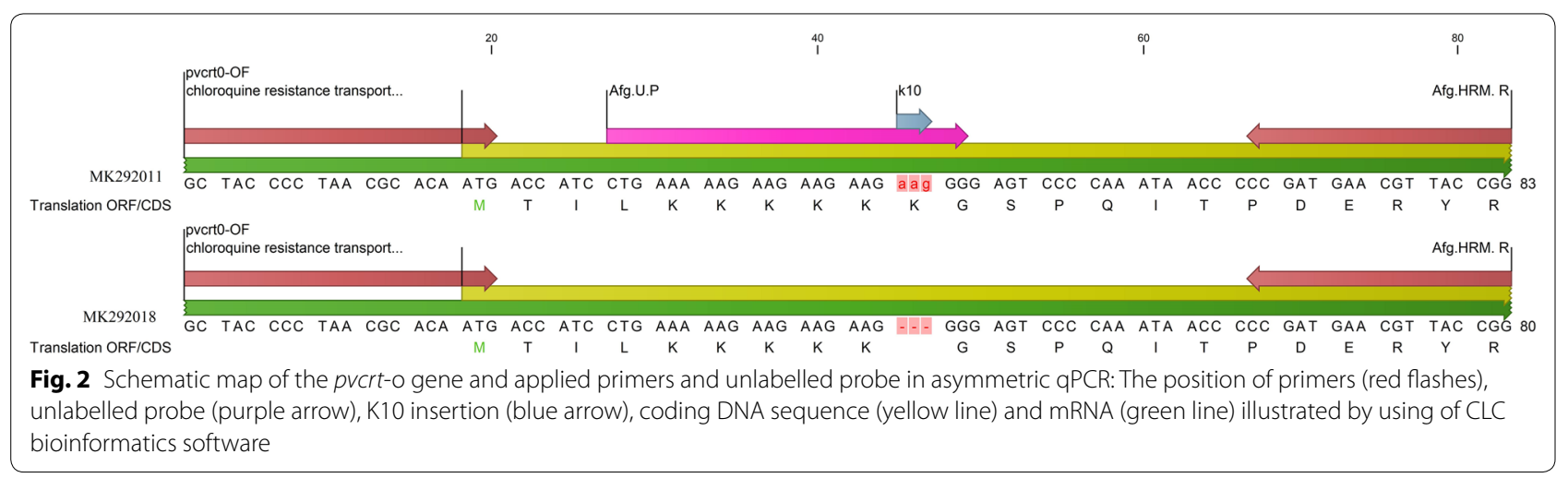




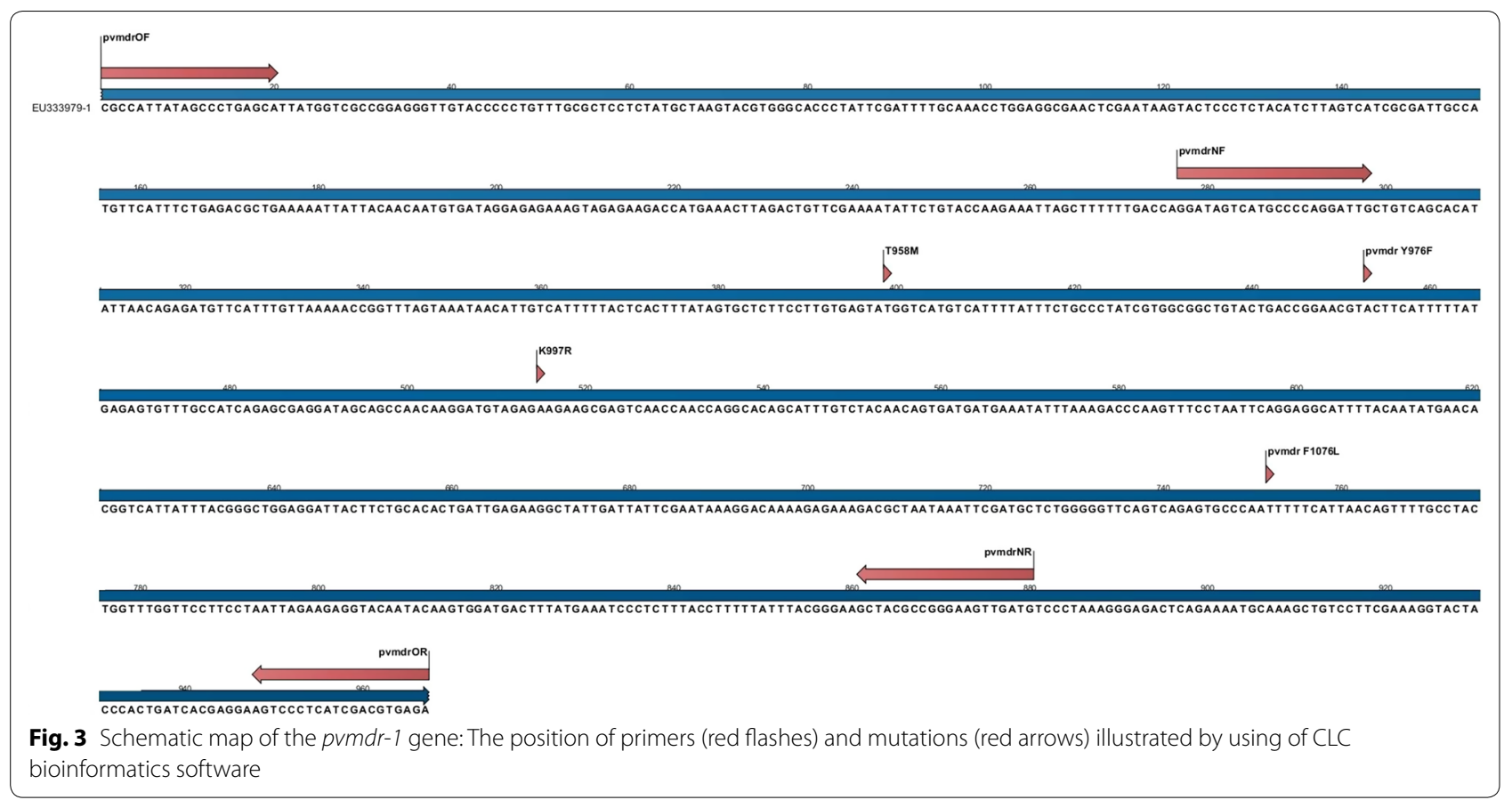

for dissociate the double stranded DNA at $95^{\circ} \mathrm{C}$ for $15 \mathrm{~s}$, gradual temperature for HRM increase from $55{ }^{\circ} \mathrm{C}$ for 1 min until $95^{\circ} \mathrm{C}$ for $15 \mathrm{~s}$ at a thermal transition rate of $0.3 \%$. Ultimately, obtained melting curve profiles were analysed by making use of HRM software for Windows ${ }^{\circledR}$ version 3.0.1. (Applied Biosystems).

\section{Results}

Verification of Plasmodium vivax samples

All microscopically confirmed $P$. vivax isolated were also verified by semi-nested multiplex PCR and then applied for evaluation of mutations in $p v m d r 1$ and pvcrt-o genes.

\section{Evaluation pvmdr1 mutations by nested-PCR}

The $p v m d r-1$ gene was successfully amplified and sequenced in $92 \%(33 / 36)$ of the $P$. vivax isolates. In spite of resequencing, $3(8 \%)$ of the samples had not acceptable sequencing results. The analysis of sequencing data of the pvmdr-1 gene (Fig. 3) showed wild type Y976 and K997 and mutant M958 and L1076 in all isolates from three provinces and submitted to GenBank, MK419882MK419914 (Table 3).

Evaluation of K10 insertion in pvcrt-o gene by unlabelled probe and semi-nested PCR

The pvcrt-o gene was successfully amplified and sequenced in $100 \%(36 / 36)$ of the $P$. vivax isolates. Of the 36 samples evaluated for K10 insertion in pvcrt-o,
Table 3 Distribution of pvmdr1 mutations among $P$. vivax isolates from Laghman, Baghlan and Khost

\begin{tabular}{|c|c|c|c|c|}
\hline \multirow[t]{2}{*}{ Mutations (SNP) } & \multicolumn{3}{|c|}{$\begin{array}{l}\text { No. isolates (\%) } \\
\text { from the following provinces }\end{array}$} & \multirow[t]{2}{*}{ Frequency (\%) } \\
\hline & Laghman & Baghlan & Khost & \\
\hline T958M (ACG/ACG) & $17(100)$ & $9(100)$ & $7(100)$ & $33(100)$ \\
\hline Y976F (TAC/TTC) & $0(0)$ & $0(0)$ & $0(0)$ & $0(0)$ \\
\hline K997R (AAG/AGG) & $0(0)$ & $0(0)$ & $0(0)$ & $0(0)$ \\
\hline F1076L (TTT/CTT) & $17(100)$ & $9(100)$ & $7(100)$ & $33(100)$ \\
\hline Total & 17 & 9 & 7 & $33(100)$ \\
\hline
\end{tabular}

Table 4 Distribution of pvcrt-o K10 insertion among $P$. vivax isolates from Laghman, Baghlan and Khost

\begin{tabular}{lllll}
\hline Polymorphism & \multicolumn{2}{l}{$\begin{array}{l}\text { No. isolates (\%) } \\
\text { from the following provinces }\end{array}$} & \multirow{2}{*}{ Frequency (\%) } \\
\cline { 2 - 4 } & Laghman & Baghlan & Khost & \\
\hline K10 Insert & $2(11.11)$ & $0(0)$ & $0(0)$ & $2(5.55)$ \\
total & 18 & 10 & 8 & $36(100)$ \\
\hline
\end{tabular}

2/18(11\%), $0 / 10(0 \%)$ and $0 / 8(0 \%)$ isolates from Laghman, Baghlan and Khost province possessed K10 insertion, respectively, that confirmed by either sequencing and unlabelled probes and submitted to GenBank, MK292011-MK292046 (Table 4). 


\section{High-resolution melting assay primer and Unlabelled probe}

Simultaneous amplification and screening of mutant and wild types of pvcrt-o gene was performed by qPCR-HRM and unlabelled probe. Unfortunately, PCR product melting transitions were not able to identify independently the genotype. The whole melting profile, showing the melting region of both the unlabelled probe and the PCR products, is shown in Fig. 1. Two peaks were apparent. If $\mathrm{K} 10$ insertion existed, the probe melted at $55.5-64{ }^{\circ} \mathrm{C}$, whereas the PCR product melted at $78.5-83{ }^{\circ} \mathrm{C}$ (Fig. 4).

\section{Discussion}

Malaria is endemic in the most parts of Afghanistan, and more than $95 \%$ of reported cases are $P$. vivax, for which chloroquine is used as first-line therapy [1]. Therefore, investigations on the frequency of mutations in the genes that are responsible for chloroquine resistance, such as pvcrt-o and pvmdr1, are needed. So far, evaluation of these mutations had not been carried out in Afghanistan and this work is the first report dealing with those mutations related to chloroquine resistance.
Y976F mutation in the pvmdr1 gene as well as the K10 insertion in the pvcrt-o gene are considered responsible for $P$. vivax resistance to chloroquine [21, 23]. The Y976F mutation is present in high-level chloroquine-resistant foci (Thailand and Myanmar) compared with low-grade regions (Republic of Korea) [32]. In a research study done in Thailand, the Y976F and the F1076L mutations were reported $23 \%$ and $53 \%$ cases, respectively [33]. In the present study, as well as the investigations that were carried out in the Republic of Korea, Madagascar and Mauritania, the F1076L mutation was reported in all the isolates studied [22, 32, 34]. Although Y976F and K997R mutations were not observed in any of the $P$. vivax isolates from Afghanistan, the presence of two mutations F1076L and $\mathrm{T} 958 \mathrm{M}$ in all isolates suggests a change in parasite genotype, which may lead to a modest positive change to reach the $C Q$ resistant phenotype.

The insertion of AAG (codon of Lysine) was present in $56.0 \%$ and $46.2 \%$ of isolates from Thailand and Myanmar, respectively. The presence of $\mathrm{K} 10$ insertion in two isolates from Laghman province, which has shown an increasing trend in cases of $P$. vivax in the last 10 years,
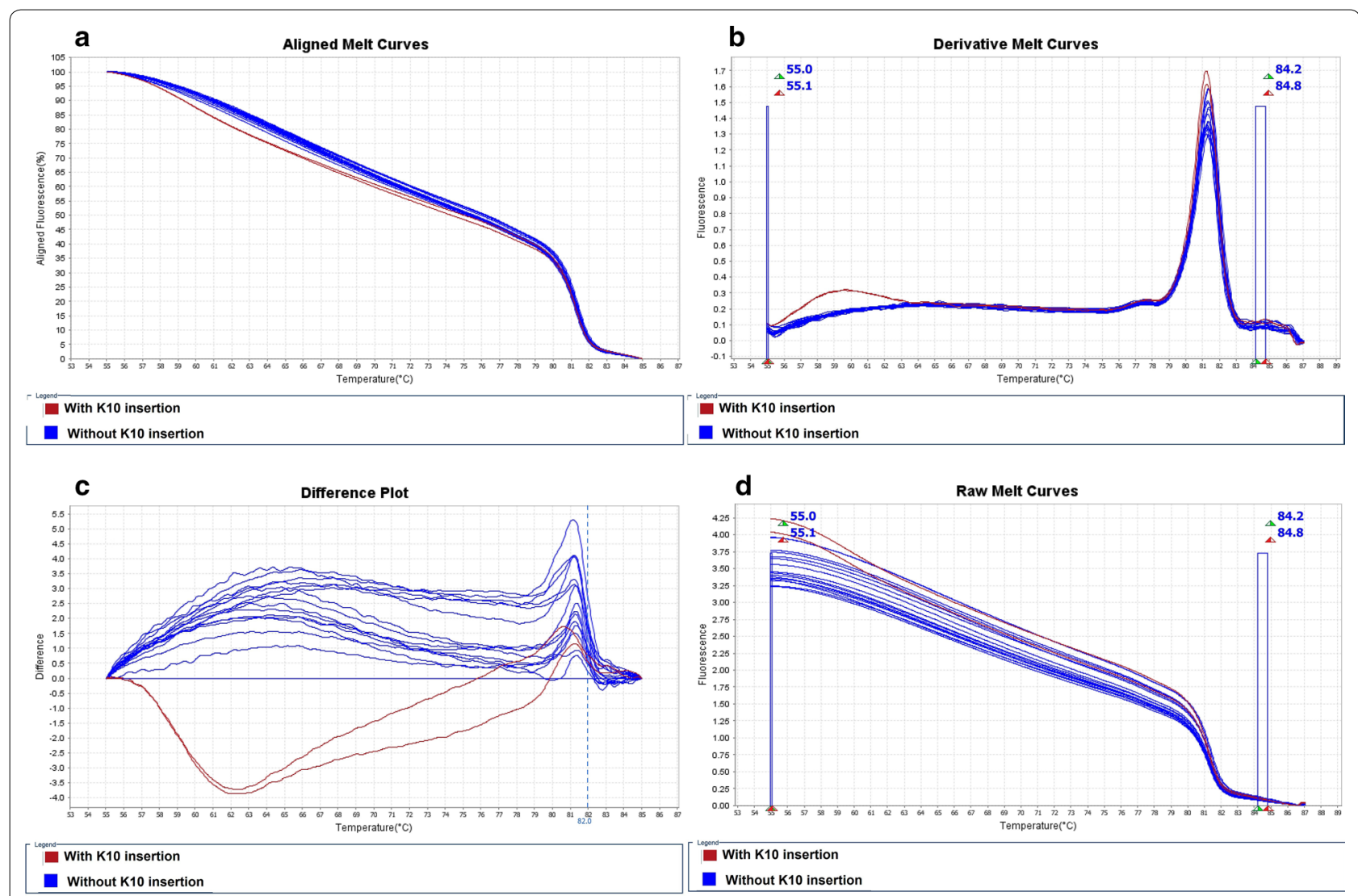

Fig. 4 Comparison of melting temperature of pvcrt-o gene mutation by unlabelled probe: a Aligned and normalized melt curves, $\mathbf{b}$ derivative melt curves, c normalized difference plot and $\mathbf{d}$ Raw Melt curve respectively. Separation of inserted (red) and non-inserted (blue) K10 variation 
is alarming, which should lead the Ministry of Public Health of Afghanistan to investigate the efficacy of chloroquine in order to improve the treatment of malaria in the country.

In several studies conducted on the pvcrt-o gene, appropriate internal primers that can replicate K10 insertion were not used, and these primers replicated on the points further, such mutations did not exist at all $[8,22$, 33]. In addition, due to the low copy number of this gene in $P$. vivax, the use of one pair of primers for amplification of the K10 insertion is not suitable for samples with low parasite loading [31].

In this study, a modified semi-nested PCR method was used to overcome those problems. In this method, two primers designed by Lu et al. were used for the first amplification of pvcrt-o gene [31]. The forward primer of first round and the Rseq primer of Glossa et al. were used in the second round [8]. Finally, sharp bands were seen suitable for sequencing. Although the sequencing is the most accurate method to detect SNPs, it is expensive, time consuming and in some circumstances impossible due to lack of infrastructures. The PCRRFLP method is cheaper and faster, but lacks sufficient enzymes for all mutations. Melt curve analysis and the use of the unlabelled probe in asymmetric qPCR is a new method used in various studies. The use of this method is much affordable since unlabelled probes are cheaper than restriction enzymes and can be transferred at room temperature. Although, HRM analysis may be enough to detect mutations, the use of an unlabelled probe signifies the accuracy of the work. The qPCR does not have postPCR manipulation problems, which are seen in DNA sequencing and PCR-RFLP. Due to financial problems, the investigation on all mutations by using the unlabelled probe method and examination of the K10 insertion was impossible.

Afghanistan is a country with other challenges, and it was not possible to investigate the copy number of the genes, to perform in vitro studies, or to study the clinical responses to $P$. vivax isolates. In fact, this work is a snapshot of CQ resistance of $P$. vivax situation in three provinces of Afghanistan. Further research needs to be performed on a larger number of samples throughout Afghanistan. There is a hope that the results of this study will be the basis for future investigations. To study the actual relationship between the mutations in the pvmdr1 and pvcrt-o genes and drug resistance, the effect of these mutations in the corresponding proteins may be studied using molecular dynamics and protein modelling, with an analysis of the possible interactions with chloroquine in silico. Genomic, transcriptomic and proteomic studies would then give a better picture of these interactions.

\section{Conclusions}

This study is an example of a study providing baseline data that may contribute to the discussion regarding the neglected status of chloroquine resistance of $P$. vivax in the region and subsequently on a global scale. The number of samples was relatively small and the results need to be taken with caution. Further in vitro and clinical observation should be done for a better understanding of chloroquine resistance in Afghanistan.

\begin{abstract}
Abbreviations
Pvcrt-o: Plasmodium vivax chloroquine resistant transporter; Pvmdr-1: Plasmodium vivax multidrug resistant; HRM: High Resolution Melting; qPCR: Quantitative Polymerase Chain Reaction; DBCs: DNA Banking Cards; RFLP: Restriction fragment length polymorphisms.
\end{abstract}

\section{Acknowledgements}

The authors would like to express their utmost gratitude to the Ghalib University, Kabul, Afghanistan for providing accommodation. Special thanks to Mr. Muhibullah Khalwati, Mr. Raies Khan Kamalzay and Mr. Mohamad Saber Ahmadzay for collecting samples from Laghman, Khost and Baghlan provinces respectively.

\section{Authors' contributions \\ SHM and NS managing the sample collection. SHM and RFA performed the bioinformatics analysis and experiments. AD corresponded the work. NS, RFA, JS and FG are the advisors. SHM and AD drafted the manuscript. All authors read and approved the final manuscript.}

\section{Funding}

This work is part of Ph.D. thesis in Medical Parasitology, supported financially by Tarbiat Modares University (Grant No. TMU.1395.1789), as well as NIMAD (National Institute for Medical Research Development) (Grant No. 971137), Tehran, Islamic Republic of Iran.

\section{Availability of data and materials}

All datasets are included within the paper. Any question may be obtained from the corresponding author upon request.

\section{Ethics approval and consent to participate}

Study protocol was reviewed and approved by Medical Ethic Committee of Tarbiat Modares University, Tehran, Iran (IR.TMU.REC.1395.401). Informed consent was taken from all people participated in this study.

\section{Consent for publication}

Not applicable.

\section{Competing interests}

The authors declare that they have no competing interests.

\section{Author details}

${ }^{1}$ Department of Medical Parasitology, Faculty of Medical Sciences, Tarbiat Modares University, Tehran, Iran. ${ }^{2}$ Medical Sciences Research Center, Ghalib University, Kabul, Afghanistan. ${ }^{3}$ World Health Organization Country Office, Kabul, Afghanistan. ${ }^{4}$ Cellular and Molecular Research Center, Qom University of Medical Sciences, Qom, Iran.

Received: 21 February 2020 Accepted: 7 July 2020

Published online: 14 July 2020

\section{References}

1. WHO. World Malaria Report 2017. Geneva: World Health Organization; 2017. 
2. Battle KE, Karhunen MS, Bhatt S, Gething PW, Howes RE, Golding N, et al. Geographical variation in Plasmodium vivax relapse. Malar J. 2014;13:144.

3. Mendis K, Sina BJ, Marchesini P, Carter R. The neglected burden of Plasmodium vivax malaria. Am J Trop Med Hyg. 2001;64:97-106.

4. Harish R, Gupta S. Plasmodium vivax malaria presenting with severe thrombocytopenia, cerebral complications and hydrocephalus. Indian J Pediatr. 2009;76:551-2.

5. Rieckmann K, Davis D, Hutton D. Plasmodium vivax resistance to chloroquine? Lancet. 1989:334:1183-4

6. Price RN, von Seidlein L, Valecha N, Nosten F, Baird JK, White NJ. Global extent of chloroquine-resistant Plasmodium vivax: a systematic review and meta-analysis. Lancet Infect Dis. 2014;14:982-91.

7. Delfini $L$. The first case of Plasmodium falciparum resistant to chloroquine treatment discovered in the Republic of Afghanistan. Trans R Soc Trop Med Hyg. 1989;83:316

8. Golassa L, Erko B, Baliraine FN, Aseffa A, Swedberg G. Polymorphisms in chloroquine resistance-associated genes in Plasmodium vivax in Ethiopia. Malar J. 2015;14:164.

9. Fernando D, Rodrigo C, Rajapakse S. Primaquine in vivax malaria: an update and review on management issues. Malar J. 2011:10:351.

10. Ezard N, Nellepalli P, Asha A. Sulfadoxine-pyrimethamine remains efficacious against uncomplicated, Plasmodium falciparum malaria in northeastern Afghanistan. Ann Trop Med Parasit. 2004;98:85-8.

11. Leslie T, Mayan I, Mohammed N, Erasmus P, Kolaczinski J, Whitty CJ, et al. A randomised trial of an eight-week, once weekly primaquine regimen to prevent relapse of Plasmodium vivax in Northwest Frontier Province, Pakistan. PLoS ONE. 2008;3:e2861.

12. Rowland M, Durrani N. Randomized controlled trials of 5-and 14-days primaquine therapy against relapses of vivax malaria in an Afghan refugee settlement in Pakistan. Trans R Soc Trop Med Hyg. 1999;93:641-3.

13. Zakeri S, Afsharpad M, Ghasemi F, Raeisi A, Safi N, Butt W, Atta H, et al. Molecular surveillance of Plasmodium vivax dhfr and dhps mutations in isolates from Afghanistan. Malar J. 2010;9:75.

14. Orjuela-Sánchez P, de Santana Filho FS, Machado-Lima A, Chehuan YF, Costa MRF, Alecrim M, et al. Analysis of single-nucleotide polymorphisms in the crt-o and mdr1 genes of Plasmodium vivax among chloroquineresistant isolates from the Brazilian Amazon region. Antimicrob Agents Chemother. 2009:53:3561-4.

15. Sá JM, Nomura T, Neves J, Baird JK, Wellems TE, del Portillo HA. Plasmodium vivax: allele variants of the mdr1 gene do not associate with chloroquine resistance among isolates from Brazil, Papua, and monkey-adapted strains. Exp Parasitol. 2005;109:256-9.

16. Nomura T, Carlton JM, Baird JK, del Portillo HA, Fryauff DJ, Rathore D, et al. Evidence for different mechanisms of chloroquine resistance in 2 Plasmodium species that cause human malaria. J Infect Dis. 2001;183:1653-61.

17. Costa GL, Amaral LC, Fontes CJF, Carvalho LH, de Brito CFA, de Sousa TN. Assessment of copy number variation in genes related to drug resistance in Plasmodium vivax and Plasmodium falciparum isolates from the Brazilian Amazon and a systematic review of the literature. Malar J. 2017; 16:152.

18. Melo GC, Monteiro WM, Siqueira AM, Silva SR, Magalhães BM, Alencar AC, et al. Expression levels of pvcrt-o and pvmdr-1 are associated with chloroquine resistance and severe Plasmodium vivax malaria in patients of the Brazilian Amazon. PLoS ONE. 2014;9:e105922.

19. Sá JM, Yamamoto MM, Fernandez-Becerra C, de Azevedo MF, Papakrivos J, Naudé B, et al. Expression and function of pvcrt-o, a Plasmodium vivax ortholog of pfert, in Plasmodium falciparum and Dictyostelium discoideum. Mol Biochem Parasitol. 2006;150:219-28.

20. Suwanarusk R, Chavchich M, Russell B, Jaidee A, Chalfein F, Barends M, et al. Amplification of pvmdr1 associated with multidrug-resistant Plasmodium vivax. J Infect Dis. 2008;198:1558-64.

21. Brega S, Meslin B, De Monbrison F, Severini C, Gradoni L, Udomsangpetch $\mathrm{R}$, et al. Identification of the Plasmodium vivax mdr-like gene (pvmdr 1 ) and analysis of single-nucleotide polymorphisms among isolates from different areas of endemicity. J Infect Dis. 2005;191:272-7.
22. Barnadas C, Ratsimbasoa A, Tichit M, Bouchier C, Jahevitra M, Picot S, et al. Plasmodium vivax resistance to chloroquine in Madagascar: clinical efficacy and polymorphisms in pvmdr 1 and pvcrt-o genes. Antimicrob Agents Chemother. 2008;52:4233-40.

23. Suwanarusk R, Russell B, Chavchich M, Chalfein F, Kenangalem E, Kosaisavee $\mathrm{V}$, et al. Chloroquine resistant Plasmodium vivax: in vitro characterisation and association with molecular polymorphisms. PLoS ONE. 2007;2:e1089.

24. Imwong M, Pukrittayakamee S, Pongtavornpinyo W, Nakeesathit S, Nair S, Newton $P$, et al. Gene amplification of the multidrug resistance 1 gene of Plasmodium vivax isolates from Thailand, Laos, and Myanmar. Antimicrob Agents Chemother. 2008;52:2657-9.

25. Vargas-Rodríguez R, da Silva Bastos M, Menezes MJ, Orjuela-Sánchez P, Ferreira MU. Single-nucleotide polymorphism and copy number variation of the multidrug resistance- 1 locus of Plasmodium vivax: local and global patterns. Am J Trop Med Hyg. 2012;87:813-21.

26. Ganguly S, Saha P, Guha SK, Das S, Bera DK, Biswas A, et al. In vivo therapeutic efficacy of chloroquine alone or in combination with primaquine against vivax malaria in Kolkata, West Bengal, India, and polymorphism in pvmdr 1 and pvcrt-o genes. Antimicrob Agents Chemother. 2013;57:1246-51.

27. Montgomery J, Wittwer CT, Palais R, Zhou L. Simultaneous mutation scanning and genotyping by high-resolution DNA melting analysis. Nat Protoc. 2007:2:59

28. Price RN, Auburn S, Marfurt J, Cheng Q. Phenotypic and genotypic characterisation of drug-resistant Plasmodium vivax. Trends Parasitol. 2012;28:522-9.

29. Mosawi S, Dalimi A. Molecular detection of Leishmania spp isolated from cutaneous lesions of patients referred to Herat regional hospital, Afghanistan. East Mediterr Health J. 2015;21:878.

30. Rubio J, Post R, van Leeuwen WD, Henry M-C, Lindergard G, Hommel M. Alternative polymerase chain reaction method to identify Plasmodium species in human blood samples: the semi-nested multiplex malaria PCR (SnM-PCR). Trans R Soc Trop Med Hyg. 2002;96:S199-204.

31. Lu F, Wang B, Cao J, Sattabongkot J, Zhou H, Zhu G, et al. Prevalence of drug resistance-associated gene mutations in Plasmodium vivax in Central China. Korean J Parasitol. 2012;50:379.

32. Lu F, Lim CS, Nam D-H, Kim K, Lin K, Kim T-S, et al. Genetic polymorphism in pvmdrl and pvcrt-o genes in relation to in vitro drug susceptibility of Plasmodium vivax isolates from malaria-endemic countries. Acta Trop. 2011;117:69-75.

33. Rungsihirunrat K, Muhamad P, Chaijaroenkul W, Kuesap J, Na-Bangchang K. Plasmodium vivax drug resistance genes; $p v m d r 1$ and $p v c r t-o$ polymorphisms in relation to chloroquine sensitivity from a malaria endemic area of Thailand. Korean J Parasitol. 2015;53:43.

34. Hu A, Noble WS, Wolf-Yadlin A, et al. Molecular surveillance of drugresistant Plasmodium vivax using pvdhfr, pvdhps and pvmdr1 markers in Nouakchott, Mauritania. J Antimicrob Chemother. 2011;67:367-74.

\section{Publisher's Note}

Springer Nature remains neutral with regard to jurisdictional claims in published maps and institutional affiliations.

Ready to submit your research? Choose BMC and benefit from:

- fast, convenient online submission

- thorough peer review by experienced researchers in your field

- rapid publication on acceptance

- support for research data, including large and complex data types

- gold Open Access which fosters wider collaboration and increased citations

- maximum visibility for your research: over 100M website views per year

At BMC, research is always in progress.

Learn more biomedcentral.com/submissions 